\title{
Tietoa ja taitoa toisen asteen verkko-opetukseen
}

\author{
ULLA HUTTUNEN
}

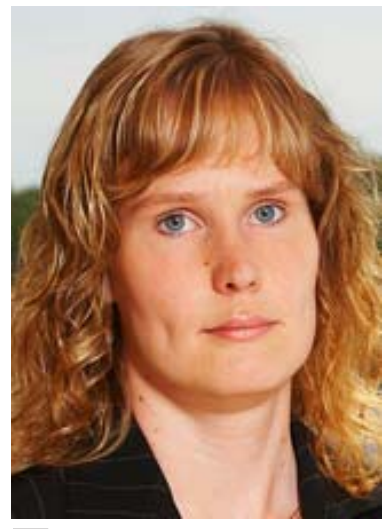

Siirtyminen perinteisestä opetuksesta verkko-opetukseen ei käy käden käänteessä. Paine lisääntyvään tieto- ja viestintäteknologian ja verkon opetuskäyttöön kuitenkin kasvaa. Verkko-opetus ja -opiskelu edellyttävät opettajilta uusia tapoja opettaa, mutta ne vaativat myös opiskelijoilta uusia tyylejä oppia. Tarvitaan virtuaalisia opetusja opiskelutaitoja. Kirjoituksessa kerrotaan Keski-Suomen Opinpolku-projektista ja sen jälkivaiheista. Opinpolku tarjosi opettajille vierikoulusta, jonka tavoitteena oli kohentaa didaktisia perustaitoja tietotekniikan opetuskäytössä. Haasteina ovat opettajien ajankäyttö, verkkodidaktiikka ja tekniikka.
Tietoverkot ovat syntyneet yhteiskuntaamme luonnollisen kehityksen tuloksena. Ne hyödyntävät monia sellaisia elementtejä, jotka ovat olleet käytössämme jo pitkään, kuten kirjeenvaihto, äänen ja kuvan vastaanotto sekä eri paikoista tapahtuva kommunikointi. Tietoverkko ei siis kokonaisuutena ole uusi tai vallankumouksellinen kommunikaatioväline. Se vaan yhdistää uudella tavalla erilaisia ja jo melko vakiintuneita viestinnän ja vuorovaikutuksen muotoja. (Matikainen 2002, 10.)

Tietoverkkojen käyttö lisää koulutuksellista tasa-arvoa, sillä verkko-opetuksen kautta voidaan taata haja-asutusalueilla asuville opiskelijoille yhtä monipuolinen tiedotus- ja kurssitarjonta kuin kaupungeissa opiskeleville. Lisäksi verkon käyttö opetuksessa monipuolistaa opetusmenetelmiä. Opiskelussa verkkoa voi hyödyntää monella eri tavalla, mm. opettajan ja opiskelijan välisessä kommunikoinnissa, tehtävien palauttamisessa, verkkokurssin kautta opiskelussa tai videoneuvottelulaitteiden välityksellä opiskelussa. Verkkoa voidaan hyödyntää tiedon jakamiseen laajemminkin, sillä esimerkiksi maakunnallisen opetustarjonnan esilletuominen keskitetysti yhden kanavan kautta onnistuu hyvin verkon välityksellä.

Verkko-opetus ei korvaa lähiopetusta ja sen antamia sosiaalisia tietoja ja taitoja. Verkko-opetus on yksi opetusmenetelmä muiden joukossa, joka sopii tiettyihin tilanteisiin. Oppilaat ovat edelleen yksilöitä oppien kukin omalla tavallaan.
Samoin myös opettajien omat opetustyylit mukautuvat ja siirtyvät verkko-opetukseen (ks. Mannisenmäki 2002, 43). Opettajat eivät opeta samalla tavalla, vaikka opetusvälineenä olisikin verkko. Yksilöllisyys säilyy myös tässä.

Verkko-opetus on yksi muutosvoimista, jonka kautta opettaja voi vaikuttaa tietoyhteiskunnan kehitykseen (Pirttimäki 2004, 9). Opettaja tarvitsee kuitenkin verkko-opetukseen siirtyessään verkkodidaktisia tietoja ja taitoja ja tukea uudenlaiseen opetusmenetelmään. Opettajaa ei saa jättää yksin kokeilujensa kanssa.

2000-luvun alussa toisen asteen oppilaitokset suosivat informaatioteknologisen koulutuksen sijasta enemmän muuta ammatillista kehittämistä, jolloin tietotekniikan opetuskäyttöön liittyvälle täydennyskoulutukselle oli tarvetta (Kangasniemi 2003, 49-50). Myös koulutuksen ja tutkimuksen tietoyhteiskuntaohjelman 2004-2006 tavoitteena oli, että tieto- ja viestintätekniikan käyttämisestä tulee osa oppilaitosten arkea, jolloin valtaosa opettajista saavuttaa tvt:n opetuskäytön taidot sekä osa opettajista tuottaa verkkoopetusmateriaalia tai - oppimisaihioita (Opetushallitus 2005, 21).

Keski-Suomessa lähdettiin maakunnallisesti tarjoamaan opettajille tieto- ja viestintätekniikan koulutusta vuosina 2003-2005 Opinpolku-projektin (http://www.opinpolku.fi) toimesta. Projekti tarjosi toisen asteen oppilaitosten opettajille 
kohdennettua, käytännönläheistä verkko-opetukseen liittyvää koulutusta. Opinpolku-projektin tavoitteena oli kehittää opettajien verkko-opetustaitoja sekä monipuolistaa maakunnallista toisen asteen opetustarjontaa mm. verkkoa hyödyntäen. Opinpolku tarjosi opettajille vierikoulusta, jonka tavoitteena oli kohentaa opettajien didaktisia perustaitoja tietotekniikan opetuskäytössä. Verkkopedagogiikan asiantuntija -koulutuksessa (VEPA-koulutus) taas perehdyttiin tarkemmin verkkokurssin suunnitteluun ja sen toteuttamiseen. VEPA-koulutus oli laajuudeltaan 3+3 opintoviikkoa ja se toteutettiin pääasiassa kouluajan ulkopuolella. Vierikoulutus ja VEPA-koulutus tukivat toisiaan ja antoivat yhdessä opettajille tietoa ja taitoa lähteä opettamaan myös verkon kautta.

\section{Oppilaitoksen verkkopedagogiikan asiantuntija}

Verkon käyttö opetuksessa monipuolistaa opetusta ja tuo uusia vaihtoehtoja opettajan työhön. Opettajan näkökulmasta katsottuna muutos ei kuitenkaan ole täysin ongelmaton. Tietoteknisten ratkaisujen lisäksi verkko-opetuksen toteutuksessa täytyy opettajan ottaa huomioon myös pedagoginen näkemyksensä. (Pirttimäki 2004, 9.) Verkkopedagogiikassa onnistumisen kannalta keskeisimmät kysymykset ovat luonteeltaan pedagogisia, eivät teknisvälineellisiä (Kiilakoski 2003, 35). Kyse on siis siitä, että opettaja osaa opettaa, oli välineenä sitten verkko tai liitutaulu.

Opettaja tarvitsee tuekseen sekä teknistä tietämystä että verkko-opetukseen liittyvää didaktiikkaa, jotta hän voi alkaa toteuttamaan verkkoopetusta mahdollisimman monipuolisesti. Kohdennettu koulutus on tällöin avainasemassa. Opinpolku-projektin Verkkopedagogiikan asiantuntija (VEPA) -koulutuksessa oli ideana perehtyä syvällisemmin verkkodidaktiikkaan, hankkia uusia teknisiä taitoja ja hahmottaa oman oppiaineensa ydin. Koulutus suunnattiin lukioiden ja ammatillisten oppilaitosten opettajille, opinto-ohjaajille ja rehtoreille.

VEPA-koulutuksen tarkoituksena oli antaa opettajille tietoa ja taitoa verkkokurssin tekemiseen ja sen pitämiseen. Koulutuksen avulla koulutettiin opettajista oppilaitoksiinsa verkkopedagogiikan asiantuntijoita, pedagogisia tukihenkilöitä, jotka voivat opastaa ja auttaa muita opettajia verkko-opetukseen liittyvissä didaktisissa ja pedagogisissa asioissa.

VEPA-koulutus piti sisällään yhdeksän kontaktikertaa, jotka kestivät kolme-neljä tuntia kerrallaan. Teoriapainotteisten luentojen lisäksi koulutuksessa aloitettiin verkkokurssin suunnittelu. VEPA-koulutuksessa perehdyttiin mm. verkkopedagogiikan ja -didaktiikan perusteisiin, verkkoon kirjoittamiseen, multimedian perusteisiin ja käytettävyyteen. Tietoteknisiä taitoja kartutettiin mm. miellekarttoja tekemällä (MindManager), kuvankäsittelyn perusteilla, animaation tekemisellä ja interaktiivisilla harjoitteilla (monivalinta- ja aukkotehtävät). Näihin ohjelmien tutustumisella haluttiin antaa opettajille eväitä käyttää hyväksi helppoja ja pääosin ilmaisia ohjelmia verkkokurssin suunnittelussa ja toteutuksessa.

Pääpaino VEPA-koulutuksessa oli omaan opetukseen liittyvän verkkokurssin suunnittelussa. Verkkokurssin käsikirjoituksen suunnittelu aloitettiin heti koulutuksen alussa ja sitä jatkettiin koko koulutuksen ajan. Verkkokurssituotannon lähtökohtana olivat lukioiden ja ammatillisten oppilaitosten opetussuunnitelmat, käytännöt ja niistä syntyvä tarve. Ideana oli, että tuotannosta syntyvät kurssit olisivat mahdollisimman monen oppilaitoksen ja oppilaan käytettävissä. Myös opettajan oma tarve verkon hyödyntämiseen opetuksessa oli tärkeää.

Verkkokurssin käsikirjoitus suunniteltiin alustasta riippumattomaksi, jonka ansiosta opettajien ei tarvinnut pohtia alustasta johtuvia teknisiä yksityiskohtia, vaan he pystyivät keskittymään sisällölliseen asiantuntijuuteensa verkkokurssin suunnittelussa. Erityistä teknistä taitoa vaativien osioiden toteuttamisessa käytettiin tarvittaessa ulkopuolista asiantuntemusta. Opettajat itse taas saivat kartuttaa verkko-opetustaitojaan VEPAkoulutuksen lisäksi vierikoulutuksessa, jossa opettajat itse tuottivat materiaalia haluamaansa verkkoympäristöön vierikouluttajan avustaessa.

Kurssikäsikirjoitusta tehtiin pääasiassa kahdenneljän hengen tuotantoryhmissä, mutta kurssikäsikirjoituksia sai tehdä myös yksin. Ryhmätyöskentelyn etuna oli, että yhden opettajan työmäärä pieneni ja kurssin suunnittelun tueksi saatiin useita eri näkökulmia. Teemojen jakaminen ja niiden työstäminen eteenpäin vähitellen tuki verkkokurssin syntymistä pala palalta.

Opettajilla oli kurssikäsikirjoitusta tehdessään koko koulutuksen ajan lähellä sekä tekninen että pedagoginen tuki. Myös koulutusjaksojen välillä ja niiden jälkeen opettajilla oli mahdollisuus saada 
tukea ja apua verkkokurssin tekemiseen. Koulutuksen aikana opittuja asioita sovellettiin heti käytäntöön oman kurssikäsikirjoituksen työstämisen kautta. VEPA-koulutuksessa tutuksi tulleet eri ohjelmat olivat käytettävissä koko koulutuksen ajan.

\section{Koulutukseen osallistuneet opettajat}

Opinpolku-projektin VEPA - koulutus järjestettiin kaksi kertaa. VEPA1-koulutus toteutettiin syksyllä 2003 ja VEPA2-koulutus syksyllä 2004. Opinpolku-projekti koulutti 44 verkkopedagogiikan asiantuntijaa Keski-Suomen toisen asteen oppilaitoksiin.

Koulutukseen osallistuneet opettajat toimivat pääasiassa opettajina ammatillisissa oppilaitoksissa ja lukioissa, muutamat olivat opettajina muissa toisen asteen oppilaitoksissa (esim. kristilliset opistot ja kansanopistot). Ammatillisten oppilaitosten opettajat olivat vahvemmin edustettuina molemmissa VEPA-koulutuksissa. Koulutettavien edustamat alat olivat hyvin monipuolisia, sillä opetettavia aineita ja aloja olivat mm. matematiikka, opinto-ohjaus, kemia, kielet, kaupanja hallinnon ala, matkailu-, ravitsemus- ja talousala, sosiaali- ja terveysala sekä luonnonvara-ala.

Koulutukseen osallistuneet opettajat olivat tieto- ja viestintäteknisten taitojen osalta hyvin eri vaiheissa ja pääosa opettajista olikin lähtötasoltaan melko alkuvaiheissa tvt-taidoissaan. Kaikille koulutettaville oli tuttua tekstinkäsittelyn perusteet ja sähköpostin käyttö. Myös yksinkertainen tiedonhaku internetistä hallittiin. Osa opettajista oli käyttänyt tietotekniikkaa hyödyksi omassa opetuksessaan jo ennen koulutusta. Pedanetia oli käytetty opetuksessa mm. materiaalipankkina ja muutama opettaja oli myös käyttänyt kuvankäsittely-ohjelmia. Useimmat opettajat olivat vasta aloittamassa opetuskokeiluja verkkomaailmassa, osalle opettajista verkko-opiskelu oli kuitenkin tuttua opiskelijanäkökulmasta.

Taitotasojen ja opetusalojen kirjavuus toi koulutukseen oman positiivisen lisänsä, sillä ryhmätyöskentelyn kautta opettajat saivat toisiltaan vinkkejä ja opastusta erilaisiin verkko-opetusmenetelmiin sekä koulutuksen edetessä myös tukea teknisiin asioihin. Koulutettavien tvt-taitojen taso koheni koulutuksen aikana ja kynnys verkon käyttöön opetuksessa madaltui.

\section{Käsitekartasta verkkokurssiksi}

Verkko-opetuksessa opettajan on ajateltava ennestään tuttuja asioita ja ongelmia uudesta viitekehyksestä (Pirttimäki 2004, 10). Oman kurssin ydinosaamisen hahmottaminen ja sen muokkaaminen verkkokurssimuotoon oli haastava tehtävä. Kurssin suunnittelu lähti useimmiten liikkeelle runsaasta materiaalista. Ensimmäistä verkkokurssia suunnittelevan opettajan oli vaikea hahmottaa kurssin tuomaa työmäärää niin opiskelijan kuin opettajan itsensä kannalta. Suunnittelun alussa kurssin sisältöön ja käsiteltäviin aiheisiin tuli runsaasti materiaalia. Kurssikäsikirjoituksen työstämisen edetessä karsiutui yleensä materiaalista noin puolet pois, jos ei enemmänkin. Alkuvaiheessa materiaalin runsaus oli väistämätöntä.

VEPA-koulutuksessa verkkokurssin käsikirjoituksen suunnittelu aloitettiin MindManagerin käsitekartalla. Opettajat tutustuivat ohjelman peruskäyttöön ja alkoivat rakentaa kurssikäsikirjoitusta käsitekarttamuotoon. Käsitekartan käytön etuna oli visuaalisuus, sillä sen avulla näki mm. kurssikäsikirjoituksen laajuuden sekä tasapainon eri osioiden kesken. Käsitekartan sisältö oli myös helppo konvertoida erilaisiksi www-sivuiksi tai erilaisiin oppimisympäristöihin.

Käsitekarttaa työstettiin koko VEPA-koulutuksen ajan ja sen tekeminen jatkui ohjattuna myös VEPA-koulutuksen jälkeenkin. Kurssikäsikirjoituksen aikana mietittiin verkkokurssin toteutusympäristöä. Osa kurssilaisista toteutti kurssinsa Pedanet-ympäristössä, osa taas konvertoi kurssin www-sivuksi ja siirsi sen sellaisenaan oppilaitoksensa palvelimelle. Suurin osa opettajista oli käyttänyt Pedanetia hyväkseen mm. tehtävien palauttamisessa ja yleisinformaation antamisessa.

Kurssikäsikirjoitusta tehdessä tulee ottaa huomioon kurssin didaktinen toteutustapa. Verkkokurssi voi olla puhdas verkkokurssi, joka ei sisällä kontaktitapaamisia tai se voi olla verkkokurssi, jossa on aloitus- ja päätöstapaamiset tai se voi olla myös yksi osa kontaktiopetusta, joka vain toteutetaan verkossa. Pelkästään verkossa toteutettava kurssi vaatii opettajalta selkeän ohjeistuksen ja aikataulutuksen, jotta opiskelijat pystyvät suorittamaan verkkokurssin itsenäisesti. Vaikka kurssi toteutetaankin yksinomaan verkon välityksellä, tulee opettajan silti näkyä verkkokurssilla ja tukea opiskelijaa oppimisessa. Kontaktitapaamisella aloitettu kurssi antaa mahdollisuuden ohjeistaa opiskelijat kasvotusten ja samalla näyttää 
kurssin rakenteen. Tällöin itse kurssin sisällä oleva ohjeistus voi olla kevyempi. Myös kontaktiopetuksen rinnalla suoritettava verkkokurssiosio antaa mahdollisuuden ohjeistaa opiskelijoita kasvotusten matkan varrella.

\section{Haasteina ajankäyttö ja tekniikka}

Verkkokurssin tekemiseen liittyi ongelmia. Ajan löytäminen kurssin tekemiseen oli niistä suurin. Koulutuksen aikana oli varattu aikaa verkkokurssikäsikirjoituksen tekemiseen, mutta sen työstämistä piti tehdä myös koulutuksen ulkopuolella. Opettajien tuntisuunnitelmissa ei vielä ollut otettu huomioon verkkokurssien tekemiseen ja pitämiseen menevää aikaa, joten aika sen tekemiseen täytyi löytää muualta. "Tavallinen” opetustyö ja sen valmistelu kuuluivat koulutukseen osallistuneiden opettajien työpäivään ja se vei osaksi myös iltoja. Sen lisäksi myös perhe-elämä vaati oman aikansa, joten vuorokaudessa käytettävät tunnit olivat rajallisia. Oli ymmärrettävää, että "ylimääräinen” verkkokurssin tekeminen ei innostanut kovin monia opettajia. Tämän vuoksi opetussuunnitelmissa ja opettajien tuntisuunnitelmissa tulisi ottaa entistä paremmin huomioon verkko-opetuksen osuus, sillä sen määrä lisääntyy koko ajan. Toisen asteen oppilaitosten kurssitarjonnassa tulee olla saatavilla riittävästi verkkokursseja, sillä opiskelijoilla on oikeus suorittaa niitä tietoverkon välityksellä vähintään kaksi opintoviikkoa (ks. Opetusministeriö 2002, 49).

Opinpolku-projekti korvasi opettajille tuntimäärän mukaan heidän verkkokurssin tekemiseen käytetyn ajan, jos oppilaitos ei korvannut sitä opetustyönä. Tällöin kurssin tekemisestä sai edes jonkinlaisen korvauksen, jos sitä teki vapaa-ajallaan. Samalla se antoi myös motivaatiota toimia oppilaitosten edelläkävijöinä.

Verkko-opetuksen teknisen ympäristön ihannetilanteessa palvelimet ja yhteydet toimivat hyvin, videoneuvotteluyhteydet toimivat, sähköpostit tulevat perille ja oppimismateriaalien suojaukset ja varmistukset ovat kunnossa. Opettaja tietää mihin tallentaa verkko-opetusmateriaalinsa ja miten se tapahtuu, oppijoilla on käytettävissään tarvittavat laitteet verkko-opiskeluun, ja ohjelmistot ovat yhteensopivia verkko-opetusmateriaalien kanssa. (Kalliala 2002, 90-91.)

Oppilaitosten verkko-opetuksen tekninen ympäristö muokkautuu pikku hiljaa kohti ihannetilannetta. Oppilaitosten laitekanta on vielä kirjavaa ja sen vuoksi verkkokurssin suunnitteluvaiheessa on jo hyvä ottaa huomioon mahdolliset tekniset rajoitukset. Ne vaikuttavat mm. verkkokurssin toteutusympäristöön ja materiaalin ulkoiseen muotoon. VEPA-koulutukseen osallistuneilla opettajilla ei ollut oppilaitoksissaan välttämättä käytössään riittäviä ohjelmia ja niiden hankkiminen oli oppilaitoksille resurssikysymys. Tämän vuoksi verkkokurssin ensimmäisissä toteutuksissa oli hyvä lähteä liikkeelle pienin askelin ja tuottaa materiaali mahdollisimman yksinkertaisin menetelmin.

Verkko-opetusta järjestävässä oppilaitoksessa tulee olla henkilöitä, jotka vastaavat siitä, että oppilaitoksen tekninen ympäristö tukee verkkoopetusta ja toimii luotettavasti. Opettajat ja oppijat tarvitsevat tiedon siitä, kenen puoleen voivat kääntyä erilaisissa verkkoon liittyvissä ongelmatilanteissa. (Kalliala 2002, 91.) Valitettavasti näin ei ole vielä kovinkaan monessa toisen asteen oppilaitoksessa. Ongelmana on teknisen tuen puute. Kaikissa oppilaitoksissa ei ole päivittäin käytettävissä teknistä tukihenkilöä. Tekninen epävarmuus osaltaan heikentää opettajien intoa toteuttaa opetusta verkon välityksellä, sillä opettajien pitäisi pystyä keskittymään verkko-opetuksen pedagogiseen ja didaktiseen toteutukseen, ei tekniseen toteutukseen.

\section{Jatkuva prosessi}

VEPA-koulutuksessa aloitetun kurssikäsikirjoituksen suunnittelu jatkui ohjattuna koulutuksen jälkeenkin. Tuotantoryhmät kokoontuivat oman aikataulunsa puitteissa työstämään kurssikäsikirjoitusta. Opinpolku-projekti koordinoi verkkokurssituotantoa ja työn edistymistä säännöllisten yhteydenottojen kautta. Myös vierikoulutus tuki tuotantoprosessia tarpeen mukaan.

VEPA-koulutuksessa tuotetut kurssit olivat laajuudeltaan 0,5-1 kurssia tai opintoviikkoa. Koulutuksessa aloitetut ja sen jälkeen valmiiksi työstetyt kurssit veivät aikaa ensimmäisen pilotoinnin vaiheeseen noin 50-80 tuntiin. Tuntimäärän hajonta oli laaja, sillä käytettyyn tuntimäärään vaikuttivat aihealue, opettajan tekniset taidot sekä kurssin rakenne.

Kun kurssikäsikirjoitus oli valmis, selvitettiin oppilaitoskohtaiset, opiskelijalähtöiset didaktiset opetusjärjestelyt. Tämän jälkeen kurssi siirrettiin sopivaan verkkoympäristöön. Koska verkkokurssikäsikirjoitus oli tehty alustariippumattomasti, 
pystyivät opettajat itse päättämään oppilaitoksensa toiminnan kannalta järkevän toteutusympäristön. Oleellista verkkoympäristön valinnassa oli käyttäjäystävällisyys ja sen toimiminen eri koneilla.

Sopivaan oppimisympäristöön siirtämisen jälkeen kurssi pilotoitiin sopivalla opiskelijaryhmällä jaksoon sopivana ajankohta. Kurssin pilotoinnista saadut kokemukset raportoitiin. Raportoinnissa otettiin huomioon sekä opettajan että oppilaiden kokemukset. Saatujen kokemusten kautta kurssia jatkotyöstettiin.

Verkkokurssi ei valmistu kerralla, vaan sen työstäminen jatkuu useiden pilottien myötä. Noin 3-4- kertaa pilotoidut kurssit alkavat olla "valmiita" verkkokursseja. Verkkokurssi ei kuitenkaan koskaan ole lopullisesti valmis, sillä sen ylläpitäminen on prosessi, joka vaatii asiatietojen ja linkkien jatkuvaa päivittämistä ja testaamista.

VEPA1 ja 2 -kursseista saatiin tuotantoon yhteensä 24 kurssia. Kursseja tehtiin mm. ympäristönsuojelusta, työpaikan hausta, metsätaloudesta, lammastaloudesta, tietotekniikasta, opintoohjauksesta ja hiukkasfysiikasta. Kursseista pilotoitiin projektin aikana 17 kurssia. Pilotoinnit koskivat joko koko kurssia tai joissakin kurssin tiettyä osiota. Valmiisiin verkkokursseihin ja oppimisaihioihin voi tutustua osoitteessa http:// www.centraali.fi.

\section{Onnistuneesti eteenpäin}

Verkkomateriaalin tuottaminen pääsi hyvään alkuun Opinpolku-projektin puitteissa. Kolmen vuoden aikana Opinpolku-projekti sai koulutettua toisen asteen oppilaitosten opettajia tuottamaan verkkokursseja oman oppilaitoksensa ja myös muiden oppilaitosten käyttöön. Tarjonta on vielä vähäistä, sillä vasta melko pieni joukko opettajista käyttää verkkoa hyväksi opetuksessaan. Muutosta saatiin kuitenkin aikaan niin opettajien asenteissa kuin oppilaitosten käytänteissäkin. Verkon käyttö opetuksessa on tulossa yhdeksi opetusmenetelmäksi muiden joukkoon eikä sitä enää koeta opetustunteja vähentävänä uhkana.

Opinpolku-projektissa tuotetut verkkokurssit ovat kaikkien oppilaitosten käytössä ja niihin on tehty yleiset opettajan ohjeet. Opettajan ohjeet takaavat sen, että kurssia voi käyttää opetuksessaan eri oppilaitosten opettajat, ei vain kurssin tuottanut opettaja.

VEPA-koulutuksessa saadut tiedot ja taidot ovat rohkaisseet opettajia hyödyntämään verkkoa opetuksessaan. Muutaman opettajan esimerkki oppilaitoksissa lisää myös muiden opettajien kiinnostusta verkon käyttöön. Pienet onnistumisen kokemukset verkkokurssin suunnittelussa ja pilotoinnissa antavat halua kokeilla myös monimutkaisempia toteutuksia verkkokurssien tuottamisessa. Uudet ideat ja toteutusmahdollisuudet syntyvät matkan varrella ja verkko-opetuksen käytänteet monipuolistuvat koko ajan.

\section{Lähteet}

Kalliala, E. (2002). Verkko-opettamisen käsikirja. Jyväskylä: Gummerus Kirjapaino Oy.

Kangasniemi, E. (2003). Millä tolalla asiat ovat? Mitä indikaattorit kertovat Suomen toisen asteen kouluista? Jyväskylän yliopisto. Koulutuksen tutkimuslaitos. Tutkimusselosteita 17. Jyväskylän yliopistopaino.

Kiilakoski, T.2003. Hyvä isäntä vai kehno renki kriittisiä näkökulmia verkkopedagogiikkaan. Aikuiskasvatus 1, 28-36.

Mannisemäki, E. 2004. Verkko-ohjaajan tehtävät ja roolit Teoksessa J. Manninen (toim.) Oppimisen ohjaus verkossa. Palamenia-sarja. Helsinki: Palmenia kustannus. 41-54.

Matikainen, J. (2002). Vuorovaikutus verkossa. Verkkopohjaiset oppimisympäristöt vuorovaikutuksen näyttämöinä. Helsinki: Palmenia kustannus.

Opetushallitus (2005). Tieto- ja viestintätekniikan opetuskäytön täydennyskoulutus. Moniste 9/2005.

Opetusministeriö (2002). Opetusjärjestelyjen monipuolistuminen ammatillisessa koulutuksessa. Opetusministeriön työryhmien muistioita 11:2002. Helsinki.

Pirttimäki, S. (2004). Yliopisto-opettajien verkkoopetuksessa kohtaamat pedagogiset haasteet. Teoksessa E. Kähkönen (toim.) Verkkooppimisen vakiintuessa. Näkökulmia ja arvioita mielekkyydestä, rahasta ja strategioista. Joensuu: Joensuun yliopistopaino. 976. 